\title{
USE OF HEDGING INSTRUMENTS ON EXAMPLE OF GRAIN MARKET
}

\author{
George Abuselidze \\ Batumi Shota Rustaveli State University, Georgia \\ george.abuselidze@bsu.edu.ge
}

\begin{abstract}
The article proves that the discrepancy of regulatory mechanisms of market relations subjects is also typical for the agricultural sector of the economy of Georgia. The problem of price formation for agricultural products is particularly acute. The research determines the need for a scientific approach to solving the issues of improving the domestic commodity market in order to ensure its adequacy for full-scale integration into the world economic space. The theoretical and methodological basis of the research is a systematic approach to the study of the fundamental provisions of the economic theory, risk management theory regarding the problems of using exchange instruments in the agricultural market of Georgia in order to minimize the risks of agricultural products. The authors have identified the main tools for protection against price fluctuations in the exchange agricultural corn market, analysed the ways to use hedging to minimize risks. The main tools of protection against price fluctuations in the exchange-traded agricultural corn market are highlighted, and the ways of using hedging to minimize risks are analysed. Since seasonality, fluctuations in production volumes, and natural and climatic conditions have a great influence on the formation of prices for agricultural products, the combined impact of these factors increases the risks of agricultural business, overcoming their negative impact on business activities in agriculture and determines the need to apply progressive elements of market regulation, including hedging tools.
\end{abstract}

Keywords: forward, futures, commodity derivatives, hedging instruments, risks, speculation.

\section{Introduction}

The crisis caused by COVID-19 completely changed the existing reality and created a completely new economic, social and political challenges $[1 ; 2]$. At the present stage of economic development of a civilized commodity exchange market, Georgia is required to introduce and apply such progressive types of exchange instruments as commodity derivatives, which would be able to protect agricultural producers from the negative factors of the economic system and ensure transparent and parity pricing. The purpose of the article is to evaluate and analyze hedging instruments, taking into account the specifics of the Georgian agricultural market.

The need to study the impact of world organized markets on the grain market of Georgia is due to the increased dependence of pricing in the domestic market on export prices for agricultural products. Export prices, in turn, are most dependent on the price situation in the world's organized markets, that is, on exchanges with future options trading in agricultural products. At the same time, given that Georgian agricultural producers are reorienting from traditional cereal crops towards expanding the acreage under corn, research on the impact of world markets on pricing for this particular grain crop is particularly relevant. The profitability of agricultural production depends on market prices for agricultural products. This factor is compounded by the lack of effective government mechanisms to influence pricing in a good market.

As the world practice shows, the use of futures markets is the most common tool for managing the price risk in agricultural markets. But due to the high degree of correlation between prices in Georgia and on international futures exchanges, Georgian farmers are becoming increasingly interested in getting up-to-date information on the futures market.

Many works of foreign and domestic scientists have been devoted to issues related to the exchange trade in commodity derivatives. In particular, foreign scientists and economists G. Abuselidze, G. Allayannis, M.J. Carrer, J. Clapp, D. Lien, B. Misund, G.S. Sahi, D.R. Sanders, L. Shao, Z. Wu, W. Zhou are engaged in research of instruments of exchange-traded derivatives markets and development of new strategies for their application [3-13] and Scientists G. Abuselidze, L. Beridze, Y. Aleskerova, N. Yamori, A.V. Gevorkyan, R. Maulida, L. Anggraeni, S.H. Pasaribu, O. Grytsyna, K. Fomichova, I. Nabok have made a significant contribution to the study of problems related to the development of the commodity exchange market [14-20].

The theoretical and empirical literature suggests that, if the futures market is to determine prices, then futures should drive spot prices. Several studies (Bohmann et al., 2019; Geman, 2009; Maynard et al 2001; Pei et al., 2014; Sahoo and Kumar, 2009; Xiao et al 2019;) investigate price discovery in the commodity futures market with mixed findings [21-27]. The authors (De Angelis and Ravid, 2016) 
prove that the hedging of commodity output is different from the hedging of commodity input [28]. In their view, firms with market power that hedge output have incentives to overproduce and distort market prices. In addition, recent research of Asche et al (2016) shows that convenient revenue in salmon forwards is related to production variables, suggesting that supply elements are important for pricing forward contracts [29]. According to Coffey and Schroeder (2019), farmers tend to use forward pricing and revenue protection insurance in combination [30]. Research articles by Boaitey (2013), Chang et al (2012), Wright (2014), Chen (2016) and others examine the grain market of the case study [31-34]. According to Chen (2016) study findings the domestic market is inefficient for farmers to distribute their products [33]. To increase the income of farmers, it is necessary to take additional expansionary policy to increase the efficiency. The authors (Collins, 2002; Dahlgran, 2009) analyze a sample of data to evaluate performance and suggest a unique movement mechanism that can make a futures contract more useful for hedgers on both sides of the market [35; 36]. According to Kavussanos, et al (2010), grain seems to be an important commodity market in order to understand what is happening in FFA markets [37].

However, the formation and development of the SOE (example, Georgian, Ukrainian, etc.) exchange market of commodity derivatives for agricultural products, its organization and regulation remain insufficiently studied and require further research.

\section{Materials and methods}

To solve these tasks, the following general scientific and special research methods were used: analysis and synthesis (to study the problems of developing the processes of insurance of risks of agricultural products with exchange instruments), scientific abstraction, induction and deduction (for systematization and generalization of domestic and foreign experience in the development of the exchange market of agricultural products); abstract-logical, dialectical (in the process of collecting, systematizing and processing information for research, as well as theoretical generalizations) comparison (for analyzing mass statistical data necessary for assessing the state, studying variations, dynamics and comparing indicators of the object of research); fundamental and correlation (to identify the interdependence between world prices for agricultural crops) correlation and regression analysis (when studying the influence of factors on the market value of grain futures) technical and trend analysis (to predict the price situation in the future), tabular and graphical methods (for visual interpretation of the research results).

\section{Results and discussion}

The difficulty of participating in the auction and the reliance on traders make exchange trading impossible for agricultural producers. This phenomenon is associated with small batches of the same type of products and inability to play on price quotes. In case of using credits, it is necessary to take into account the seasonality of agricultural products and the corresponding payment schedule. A classic is a bank loan that provides interest on it. However, the financial situation of medium-and small-scale agricultural enterprises and individual farms is difficult, and banks refuse to provide loans [38-42].

In market conditions, agricultural producers' advances are made through forward transactions. Therefore, let us consider the availability of tools for various categories of market participants.

\section{Availability of exchange-traded and OTC instruments for various participants in the agricultural sector}

\begin{tabular}{|c|c|c|c|c|c|}
\hline $\begin{array}{c}\text { Types of operators and } \\
\text { the tools available }\end{array}$ & $\begin{array}{c}\text { Futures } \\
\text { contract }\end{array}$ & $\begin{array}{c}\text { Minimum } \\
\text { price } \\
\text { contract }\end{array}$ & $\begin{array}{c}\text { Option } \\
\text { contract }\end{array}$ & $\begin{array}{c}\text { Physical or } \\
\text { spot market }\end{array}$ & $\begin{array}{c}\text { Forward } \\
\text { agreement }\end{array}$ \\
\hline Farmers & No & Yes & No & Yes & Yes \\
\hline $\begin{array}{c}\text { Agricultural holdings } \\
\text { with offshore offices }\end{array}$ & Yes & Yes & Yes & Yes & Yes \\
\hline International trader & Yes & Yes & Yes & Yes & Yes \\
\hline Intermediary trader & No & Yes & No & Yes & Yes \\
\hline
\end{tabular}


Middleman traders and farmers can use the "minimum price contract" as an alternative hedging option, because Exchange-traded instruments are not available to them. So, a "minimum price contract" is a forward transaction that establishes a cash sale for a known quantity and quality of any product for the nearest or deferred shipment period. It is widespread in Georgia to set a minimum cash price, which makes it impossible for various entities to enter the exchange market to conclude options contract. The advantages of this type of agreement are:

- ability to catch an increase in the price level of a futures contract by increasing the option premium;

- ability to fix the final price on the physical market at any time;

- provide some leverage to get a loan;

- limited risk;

- value of the contract is often negotiable (i.e., a contract may be less than 5000 bushels);

- no need to deal directly with the options market;

- allows to set a minimum price and helps make decisions in production management.

Among the disadvantages are the following:

- the futures price may go down, which may result in the loss of the premium that the operator will pay for the deduction agreement for the call option;

- the person entering into this agreement is subject to the collection of service fees, which include the price for purchasing a call option, which is determined based on the strike price you took, price volatility, and time value;

- the product must be delivered to a specific elevator.

Consider an example of how the "minimum price contract" works in practice. For example, on October 1, a person decided that you needed to sell some of the grain in order to free up funds to cover other needs. However, you feel that the futures price has the potential to increase. You have decided to enter into an agreement with a minimum price that expires on February 24.

Today-January 1: Sale price in January: -7.50 USD; Premium paid for a call option: -0.65 USD;

Fee-for-service (for this example): -0.15 USD; Minimum contract price: 7.00 USD.

\section{Scenario 1: February 1-Prices went up}

Minimum price for October 1: 7.00 USD;

Premium paid for a call option: + 0.75 USD;

New spot price: 7.75 USD.

In case of growth of the price of March, it is possible to sell the option, liquidating the trading result with a profit of 0.65 USD from the minimum contract price and a net price increase in the physical market of 0.15 USD instead of selling on January 1 in the physical market.

Scenario 2: February 1-Prices fell

Minimum price for October 1: 7.75 USD;

Premium paid for a call option: + 0.25 USD;

New spot price: 8.00 USD.

This decrease in the price of the call option indicates that the price of the March has decreased. Although you will get an increase in the minimum price as a result, the price on the physical market is lower than the spot price when you could have made a sale on January 1 at 7.50 USD [43].

Even a small change in the price of agricultural products can have a significant impact on the sales margin in general, hence the question: Sell or expect prices to rise?

Today in the Georgian market there are many options for how to sell agricultural products. Starting from the delivery by the elevator or the car, delivery to the port and ending with the sale to the final buyer on the terms of delivery to the buyer's country. In fact, the most popular way is to sell grain at the elevator. This is mainly due to the fact that in this case there are fewer risks, as well as the "headache" that can occur when selling on the terms of the CPT-port. After all, logistics issues remain open, and you need to have a reliable forwarder in your arsenal, but this cannot guarantee that there are no problems 
faced by Georgian manufacturers. However, as a rule, you can get a higher price when selling at the port, even after deducting the cost of logistics.

In addition, most traders are ready to build long-term relationships with Georgian farmers and work on forward contracts. The forward contract allows the producer to sell the new crop of corn in spring or summer and not in the fall when the country is collecting and growing corn. After all, the harvest season puts pressure on prices, and they fall, after which the farmer is forced to both sell at a low price or store corn until the spring or summer of the next year, when the market "comes to its senses" and at the same time bear the cost of storage.

An excellent example of the effectiveness of forward contracts in Georgia is 2019. Starting from spring and almost until mid-June corn prices both in the world and in Georgia grew rapidly. This was largely due to fears for the harvest of the United States, where, as expected by the majority of analysts, dry weather conditions can damage the corn crop. However, with the appearance of rains in the United States corn belt, all fears were refuted, and corn prices around the world began to decline (Fig. 1).

Published on Investing.com, 16/Aug/2020 - 20:29:13 GMT, Powered by TradingView.

Фьючерс на кукурузу США, (CFD):ZC, w

EMA (9, close, 0$)$

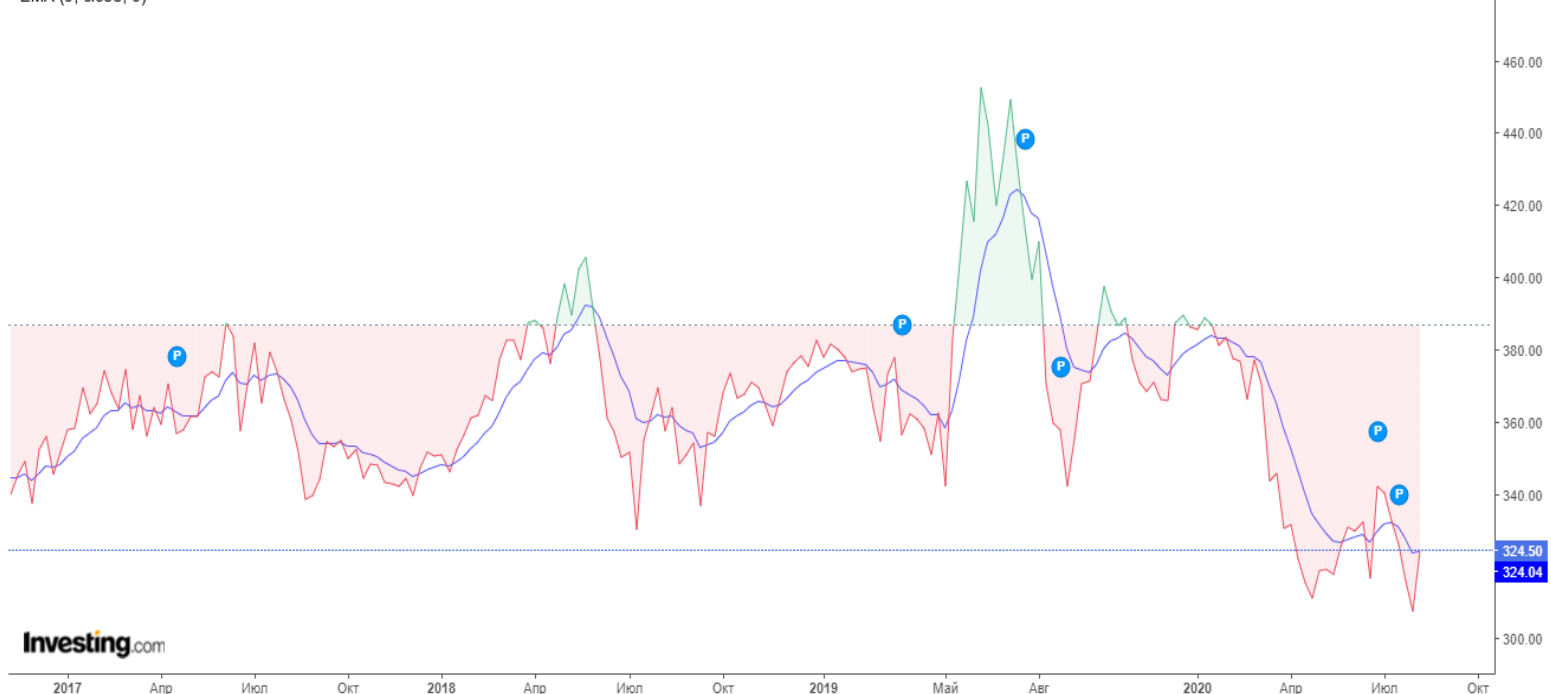

Fig. 1. Futures prices for corn: Source: United States Department of Agriculture (2020); National Agricultural Statistics Service (2020) [44-46]

Future contract holders received by 10-20 \$/t higher the price than it was in September 2019, but it must be taken into account that this is not even the peak of the harvest pressure on prices in Georgia. Based on this, today in the Georgian market there are many tools to build an effective strategy for the implementation of their crop. In fact, each individual enterprise needs to build a separate strategy based on the specifics of what grows the economy, how strong is the need for cash flow, is it possible to store or you want to attract the elevators.

Unfortunately, there are no opportunities to enter into a forward contract for the supply of next year's corn on the physical market of Georgia. By the way, a forward contract is the cheapest and easiest way to hedge (protect) price risks. By signing this agreement with the buyer of corn, the farmer fixes the sale price and is no longer afraid of falling prices in the market. The only question is the reliability of the buyer and his desire to perform a forward transaction in the event that prices fall significantly during the delivery period. The forward contract is not standardized; it can be concluded for different volumes and quality of corn, with different delivery terms and conditions. This is certainly the advantage of a forward contract. But it is not always possible to enter into a forward contract. For example, it is very difficult to find a buyer of corn on the physical market under forward contracts long before the delivery time and even when the price is predicted to fall. This is probably how the situation on the corn market will develop (pessimistic option), that is, prices will fall, and for the delivery period (OctoberNovember) the price will be $145-160 \$ / t$ on the terms of FOB deep-sea ports of the Black sea. But this price does not suit us in terms of the planned profitability. Therefore, we decide to hedge part of our corn production $(10 \%)$ from the fall in the price for selling not a physical commodity under a forward 
contract (we do not have this option), but the sale of ten corn futures on the Chicago Board of Trade (CBOT).

The agro-industrial sector includes the TOP 10 most liquid futures in the world and corn futures are almost the only commodity futures among them (Table 2 ).

Table 2

Most liquid futures for agricultural products

\begin{tabular}{|cccc|}
\hline Globex & Product Name & Volume & Open Interest \\
\hline ZC & Corn Futures & 231372 & 1689175 \\
\hline OZC & Corn Options & 90258 & 1278591 \\
\hline OZS & Soybean Options & 196097 & 1039653 \\
\hline ZS & Soybean Futures & 386372 & 957850 \\
\hline ZL & Soybean Oil Futures & 159134 & 495250 \\
\hline ZM & Soybean Meal Futures & 123724 & 436182 \\
\hline ZW & Chicago SRW Wheat Futures & 75120 & 385676 \\
\hline OZW & Chicago SRW Wheat Options & 18784 & 299258 \\
\hline OZL & Soybean Oil Options & 13471 & 293436 \\
\hline KE & KC HRW Wheat Futures & 22980 & 211537 \\
\hline OZM & Soybean Meal Options & 16502 & 198298 \\
\hline OKE & KC HRW Wheat Options & 1410 & 45687 \\
\hline
\end{tabular}

Source: Made by the author using following data [47-49]

Next on the market are futures for soybeans, soy oil and wheat, and soy flour. The average daily volume of corn contract trading on the CBOT exchange was Q3 2019 358.547. Electronic trading covers $91 \%$ of the total trade volume of the assets. The size of the open interest is 1689175 . Futures are presented under the Ticker ZC:

- the contract is traded from Monday to Friday from 2:00 to 21:15.

- the exchange has a break for this asset from 15:15 to 17:30.

- contract months include March, may, July, September, and December.

- the expiration date occurs on the last business day before the 15 th calendar day of the delivery month.

- the size of the corn futures contract is 5000 bushels, and the price is indicated for 1 bushel of raw materials.

- the minimum price change is 0.25 (12.5 USD when purchasing a full contract).

On average, the Chicago Mercantile exchange (Chicago Board of Trade) carries out about two hundred thousand transactions per working day with the nearest futures contract for corn, which causes price changes several dozen times per second and makes this market very liquid [50]. The largest number of corn futures contracts is held on the Chicago Board of Trade. Therefore, for hedging price risks, the Chicago Board of Trade (CBOT) is more often used and trading positions are opened on this exchange. Note that corn futures are traded on CBOT exclusively of American origin with the possibility of physical delivery to American elevators, so it is very important for Georgian producers to have information about the price difference between the physical corn market in Georgia and the corn futures market on CBOT.

The increase in corn prices also leads to an increase in futures contract prices. In this case, we get a profit from holding the futures contract and can fix this profit by selling the futures contract. Conversely, when the price of corn decreases, we will receive losses from holding the futures contract and have to top up the deposit. In addition, we will have to pay our broker a commission fee for the purchase or sale of a futures contract made for us. Such payment is not provided for in forward contracts.

In case of delivery in March, the price of 1 ton of corn is 240 USD in CPT conditions and it depends on the yield per hectare. However, corn is sown in spring and harvested in the fall. But we cannot fix this price for the next year's crop back; because there are no physical buyers who wanted to buy new crop corn today. In other words, the physical market is not working yet. 
In addition to the physical market, there is also a corn futures market, for example, at the Chicago chamber of commerce CBOT. If the futures contract is sufficiently liquid, we can use it to hedge our price risks. The hedge works because physical and futures corn prices tend to rise or fall simultaneously, so losses on one side of the hedge are offset by gains on the other. If physical corn prices fall in the future, the money we lose in the physical market will be offset by the gains from taking a short position in the corn futures market. Hedging is possible when the cash price of corn and the price of corn futures are equal at the moment of delivery. In such a case futures markets function properly, otherwise it is impossible to hedge.

\section{Conclusions}

Historically, the stock market has provided real commodity to execute short futures positions to equalize cash and futures prices. When cash prices are much higher than futures prices, trading arbitrators buy features, then sell a physical commodity on the cash market at an inflated price and make a profit. Such actions of arbitration allow to increase the pressure on the price of money and equalize prices.

Conversely, when futures prices run out and begin to far exceed the SPOT (physical market) prices, arbitragers sell futures, buy physical goods, store them, and deliver them in accordance with the terms of the futures contract. This continues until the cash and futures prices are aligned, reducing the potential profit of arbitragers. Possibility of hedging is due to prices (for physical corn and for corn futures) correlation, which in turn is conditioned by arbitragers.

Hedging allows the risks posed by various circumstances to become stable. The use of hedging technologies in the agricultural sector by the manufacturers is an important factor both in Georgia and in other countries of the world.

\section{References}

[1] Abuselidze G., Mamaladze L. The Impact of the COVID-19 Outbreak on the Socio-Economic Issues of the Black Sea Region Countries. Lecture Notes in Computer Science, vol. 12253, 2020, pp. 453-467. Springer, Cham. DOI: 10.1007/978-3-030-58814-4_32

[2] Abuselidze G., Mamaladze L. The impact of artificial intelligence on employment before and during pandemic: A comparative analysis. Journal of Physics: Conference Series, 1840, 2021. 012040 p. DOI: 10.1088/1742-6596/1840/1/012040

[3] Abuselidze G. Georgia's Capital Market: Functioning Problems and Development Directions in Association with European Union. Journal of Applied Economic Sciences, vol. 13(7), 2018, pp. 1929-1938.

[4] Allayannis G., Ofek E. Exchange rate exposure, hedging, and the use of foreign currency derivatives. Journal of international money and finance, vol. 20(2), 2001, pp. 273-296. DOI: 10.1016/s0261-5606(00)00050-4

[5] Carrer M. J., Silveira R.L.F.D., Souza Filho H. M. D. Factors influencing hedging decision: evidence from Brazilian citrus growers. Australian Journal of Agricultural and Resource Economics, vol. 63(1), 2019, pp. 1-19. DOI: 10.1111/1467-8489.12282

[6] Clapp J., Helleiner E. Troubled futures? The global food crisis and the politics of agricultural derivatives regulation. Review of International Political Economy, vol. 19(2), 2012, pp. 181-207. DOI: $10.1080 / 09692290.2010 .514528$

[7] Lien D., Zhang M. A survey of emerging derivatives markets. Emerging Markets Finance and Trade, vol. 44(2), 2008, pp. 39-69. DOI: 10.2753/REE1540-496X440203

[8] Misund B., Asche F. Hedging efficiency of Atlantic salmon futures. Aquaculture Economics \& Management, vol. 20(4), 2016, pp. 368-381. DOI: 10.1080/13657305.2016.1212123

[9] Sahi G.S. Influence of Commodity Derivatives on Volatility of Underlying Asset. ICFAI Journal of Derivatives Markets, vol. 4(3), 2007.

[10] Sanders D. R., Irwin S. H., Merrin R. P. The adequacy of speculation in agricultural futures markets: too much of a good thing?. Applied Economic Perspectives and Policy, vol. 32(1), 2010, pp. 77-94. DOI: 10.1093/aepp/ppp006 
[11] Shao L., Shao J., Sun Z., Xu H. Hedging, speculation, and risk management effect of commodity futures: Evidence from firm voluntary disclosures. Pacific-Basin Finance Journal, vol. 57, 2019, 101084 p. DOI: $10.1016 /$ j.pacfin.2018.10.013

[12] Wu Z., McERLEAN S. Market efficiency in the reformed Chinese grain marketing system. China Economic Review, vol. 14(2), 2003, pp. 115-130. DOI: 10.1016/s1043-951x(02)00056-1

[13] Zhou W. The role of the state in making a national market. China Agricultural Economic Review, vol. 2(3), 2010, pp. 276-297. DOI: 10.1108/17561371011078426

[14] Abuselidze G. European Integration of Georgia and Financial-Economic Condition: Achievements and Challenges. European Journal of Sustainable Development, vol. 8(1), 2019, pp. 53-68. DOI: 10.14207/ejsd.2019.v8n1p53

[15] Fomichova K. Trends in the Grain Market of Ukraine. Food Industry Economics, vol. 9(1), 2017. DOI: $10.15673 /$ fie.v9i1.483

[16] Yamori N. Co-Movement between Commodity Market and Equity Market: Does Commodity Market Change?. Modern Economy, vol. 02(03), 2011, pp. 335-339.

DOI: 10.4236/me.2011.23036

[17] Abuselidze G., Beridze L. The Role of Alternative Investments in the Development of Capital Markets: in Terms of the Transformation of Georgia with the EU. In: Proceedings of the 4th International Conference on European Integration (ICEI), 2018, pp. 29-41.

[18] Gevorkyan A. V. Exchange market pressure and primary commodity - exporting emerging markets. Applied Economics, vol. 51(22), 2018, pp. 2390-2412.

DOI: $10.1080 / 00036846.2018 .1545077$

[19] Maulida R., Anggraeni L., Pasaribu S. H. Testing on Market Efficiency of the Cacao Commodity for the Futures Market in Jakarta Future Exchange. Jurnal Manajemen Dan Agribisnis, vol. 15(1), 2018, pp. 53-60. DOI: 10.17358/jma.15.1.53

[20] Nabok I., Hryhorieva I. Application of incoterms 2020 rules on the grain products market. Market Infrastructure, vol. 38, 2019. DOI: 10.32843/infrastruct38-6

[21] Bohmann M. J., Michayluk D., Patel V. Price discovery in commodity derivatives: Speculation or hedging? Journal of Futures Markets, vol. 39(9), 2019, pp. 1107-1121. DOI: 10.1002/fut.22021

[22] Geman H. Commodities and commodity derivatives: modeling and pricing for agriculturals, metals and energy. John Wiley \& Sons. 2009.

[23] Maynard L. J., Hancock S., Hoagland H. Performance of shrimp futures markets as price discovery and hedging mechanisms. Aquaculture Economics \& Management, vol. 5(3-4), 2001, pp. 115-128. DOI: DOI: 10.1080/13657300109380282

[24] Pei Q., Zhang D. D., Xu J. Price Responses of Grain Market under Climate Change in Preindustrial Western Europe by ARX Modelling. Proceedings of the 4th International Conference on Simulation and Modeling Methodologies, Technologies and Applications, 2014.

DOI: $10.5220 / 0005025208110817$

[25] Sahoo P., Kumar R. Efficiency and futures trading-price nexus in Indian commodity futures markets. Global Business Review, vol. 10(2), 2009, pp. 187-201.

DOI: $10.1177 / 097215090901000204$

[26] Xiao X., Tian Q., Hou S., Li C. Economic policy uncertainty and grain futures price volatility: evidence from China. China Agricultural Economic Review, vol. 11(4), 2019, pp. 642-654. DOI: $10.1108 /$ caer-11-2018-0224

[27] Alhaj A. A., Awn A. M. Financial Instruments and their Impact on the Growth of Investment - A Study on the Libyan Market. European Journal of Economic and Financial Research, vol. 4(3), 2020, pp. 158-173. DOI: $10.46827 /$ ejefr.v4i3.952

[28] De Angelis D., Ravid S. A. Input Hedging, Output Hedging, and Market Power. Journal of Economics \& Management Strategy, vol. 26(1), 2016, pp. 123-151. DOI: 10.1111/jems.12180

[29] Asche F., Misund B., Oglend A. The spot-forward relationship in the Atlantic salmon market. Aquaculture Economics \& Management, vol. 20(2), 2016, pp. 222-234.

DOI: $10.1080 / 13657305.2016 .1156192$

[30] Coffey B. K., Schroeder T. C. Factors influencing Midwestern grain farmers' use of risk management tools. Agricultural Finance Review, vol. 79(2), 2019, pp. 192-203. DOI: 10.1108/AFR-04-2018-0026 
[31] Boaitey A. Grain market deregulation: a case study of the Canadian and Australian wheat boards. Journal of Public Affairs, vol. 13(3), 2013, pp. 282-287. DOI: 10.1002/pa.1467

[32] Chang C. L., Chen L. H., Hammoudeh S., McAleer M. Asymmetric adjustments in the ethanol and grains markets. Energy economics, vol. 34(6), 2012, pp. 1990-2002. DOI: $10.1016 /$ j.eneco.2012.07.026

[33] Chen S. Grain Market Integration and Distribution Efficiency in Guizhou, China: Comparison of Rice and Soybeans. Studies in Regional Science, vol. 46(4), 2016, pp. 387-399. DOI: $10.2457 /$ srs.46.387

[34] Wright B. Global biofuels: key to the puzzle of grain market behavior. Journal of Economic Perspectives, vol. 28(1), 2014, pp. 73-98. DOI: 10.1257/jep.28.1.73

[35] Collins R. A. The economics of electricity hedging and a proposed modification for the futures contract for electricity. IEEE Transactions on Power Systems, vol. 17(1), 2002, pp. 100-107. DOI: $10.1109 / 59.982199$

[36] Dahlgran R. A. Inventory and transformation hedging effectiveness in corn crushing. Journal of Agricultural and Resource Economics, vol. 34(1), 2009, pp. 154-171. DOI: 10.2307/41548406

[37] Kavussanos M., Visvikis I., Dimitrakopoulos D. Information linkages between Panamax freight derivatives and commodity derivatives markets. Maritime Economics \& Logistics, vol. 12(1), 2010, pp. 91-110. DOI: 10.1057/mel.2009.20

[38] Abuselidze G. Modern Challenges of Monetary Policy Strategies: Inflation and Devaluation Influence on Economic Development of the Country. Academy of Strategic Management Journal, vol. 18(4), 2019, pp. 1-10.

[39] Abuselidze G. Optimality of Tax Policy on the basis of Comparative Analysis of Income Taxation. European Journal of Sustainable Development, vol. 9(1), 2020, pp. 272-293.

DOI: $10.14207 /$ ejsd.2020.v9n1p272

[40] Abuselidze G., Gogitidze I. Tax policy for business entities under the conditions of association with the European Union: features and optimization directions. E3S Web of Conferences, vol. 166, 2020. 13013 p. DOI: $10.1051 / \mathrm{e} 3$ sconf/202016613013

[41] Abuselidze G., Kizinidze M. Influence of central bank regulations on interbank competition in association with EU. E3S Web of Conferences, vol. 135, 2019.04037 p. DOI: $10.1051 / \mathrm{e} 3$ sconf/201913504037

[42] Abuselidze G. The Impact of Banking Competition on Economic Growth and Financial Stability: An Empirical Investigation. European Journal of Sustainable Development, vol. 10(1), 2021, pp. 203-220. DOI: 10.14207/ejsd.2021.v10n1p203

[43] Grain Marketing Contracts: Minimum Price Contract, 2020. [online] [31.08.2020]. Available at: https://admadvantage.com/.

[44] United States Department of Agriculture: Prices Received: Corn Prices Received by Month, US. 2020. [online] [31.08.2020]. Available at: https://www.nass.usda.gov/Charts_and_Maps/Agricultural_Prices/pricecn.php.

[45] National Agricultural Statistics Service: Prices Received: Corn Prices Received by Month, US. 2020. [online] [31.08.2020]. Available at:

https://www.nass.usda.gov/Charts_and_Maps/Agricultural_Prices/pricecn.php.

[46] National statistics office of Georgia. Food Security, 2020. [online] [08.03.2021]. Available at: https://www.geostat.ge/en/modules/categories/297/food-security.

[47] Rural Development Agency, 2021. [online] [08.03.2021]. Available at: http://rda.gov.ge/main.

[48] Agriculture analytical Agency: Statistics, 2020. [online] [31.08.2020]. Available at: http://www.agriagency.com.ua/subscription/statistics/.

[49] Cme group. Data, 2020. [online] [31.08.2020]. Available at: https://www.cmegroup.com/marketdata.html.

[50] Cme group. Tools and Resources, 2020. [online] [31.08.2020]. Available at: https://www.cmegroup.com/tools-information/. 